\title{
Health empowerment: Universal health care for the underprivileged
}

\author{
J Mukhopadhyay
}

Associate Professor, Dept. of Community Medicine, NC Medical College, Panipat, India

Corresponding Author:

Email: jmukho@yahoo.co.in

Poverty is a universal problem especially so in India that unwaveringly relates to ill health with higher mortality rates. ${ }^{1}$ World Bank estimated around 270 million Indians living 'Below Poverty Line' which depicts approximately 1 in 5 individual in general of whom $45 \%$ are illiterate. ${ }^{2} 80 \%$ of poor Indians live in rural areas and work as casual labor in agricultural farm and small scale industries. They have limited access to food, clean water and safe shelter; the poverty stricken children experience limitations in development and opportunities for education extending into adulthood. ${ }^{3}$ Difficulty in access to healthcare is another common problem among poor families. Payment for healthcare can divert the limited disposable income from other day-to-day needs of these families. Therefore, it is natural that poverty and poor health run hand-in-hand revolving round a vicious cycle lasting for generations in the family. ${ }^{4}$ Media, newspaper, TV broadcast hardly publicize any agenda on poorer section instead try to instill the glimmers and glitters of the rich by portraying golden life of celebrities among the common.

WHO pronounced Alma-Ata Declaration in 1978 stating that 'primary healthcare is the key to health for all' and that was further re-emphasized as 'Primary Health Care - Now More than Ever' in 2008. ${ }^{5}$ Primary healthcare starts with self-care to promote health, prevent disease and manage illnesses. Health is profoundly prejudiced by extramural issues beyond the health domain, especially by socio-demographic, environmental, economic and political counts. These forces largely shape the circumstances in which people subsist, nurture, work and mature as well as utilize the existing systems to deal with health needs ultimately quivering into inequities in health within communities. ${ }^{6}$ Health empowerment, a central component of health promotion and disease prevention, refers to a process through which people gain greater control over the decisions taken on their lives and health. The concept of health empowerment is to educate and enable individuals and families so that they can have the knowledge, motivation, self-efficacy, means of action and resources to stay healthy and seek health services appropriately. Provence of knowledge would transform into wisdom of action in the face of challenges for life and health. To counter the challenges due to the changing scenarios in social, demographic, epidemiological, food security, environmental, and financial front, health empowerment has emerged as an important tool; a novel and contemporary approach that needs no exaggeration. 'Health Promotional Hospitals' have been reformed in India by restructuring renowned tertiary care hospitals considering the need of the hour. ${ }^{7}$ Efforts are needed to build more health promoting setups like schools, hospitals and work places for empowering the poor. ${ }^{7}$ Empowerment of the underprivileged by enhancing health literacy through health education and mitigating their medico-social and psycho-emotional demand will go a long way to resolve the prevailing disparity.

\section{References}

1. Wagstaff A. Poverty and health sector inequalities. Bull World Health Org. 2002; 80(2): 97-105.

http://www.who.int/bulletin/archives/80(2)97.pdf

2. World Bank. India's Poverty Profile. 2016 http://www.worldbank.org/en/news/infographic/2016/05/ 27/india-s-poverty-profile

3. Duncan GJ, Yeung WJ, Brooks-Gunn J, Smith JR. How much does childhood poverty affect the life chances of children? Am Sociological Rev 1998; 63(3): 40623 doi: $10.2307 / 2657556$

4. Yoshikawa H, Aber JL, Beardslee WR. The effects of poverty on the mental, emotional, and behavioral health of children and youth: Implications for prevention. Am Psychology, 2012; 67(4): 272-84. doi:10.1037/a0028015

5. World Health Organization. The world health report 2008, Primary health care: Now more than ever. Geneva, Switzerland: World Health Organization, 2008. Google Scholar

6. WHO. Geneva. Commission of Social Determinants of Health. Closing the gap in a generation: health equity through action on the social determinants of health. Final Report of the Commission on Social Determinants of Health. 2008.

www.who.int/social_determinants/thecommission/finalre port/en/

7. Goel S, Gupta AK, Ahuja P, Jain BU, Bains P, Goel S, Singh A. Comparison of the health promoting orientation of three tertiary care hospitals of India. National Medical Journal of India. 2011; Vol. 24(2): 83-85. http://archive.nmji.in/archives/Volume-24/Issue-2/ShortReport.pdf 